\title{
Methodology based on micro-projects in DIY desktop machines for educational purposes in engineering degrees
}

Pernía-Espinoza, Alpha ${ }^{a}$; Sanz-García, Andres ${ }^{b}$; Sodupe-Ortega, Enrique ${ }^{a}$; Antoñanzas-Torres, Javier ${ }^{a}$; Antoñanzas-Torres, Fernando ${ }^{a}$; Urraca-Valle, Ruben ${ }^{a}$ ${ }^{a}$ EDMANS Research Group, Department of Mechanical Engineering, University of La Rioja, Spain, ${ }^{b}$ Faculty of Pharmacy, Centre of Drug Research (CDR), University of Helsinki, Finland.

\begin{abstract}
The $21^{\text {st }}$ century university has the big educational challenge of how to encourage "a will to learn" in students living in a world saturated with a huge amount of information and distractions. A needed step to keep students motivated is to update their learning environments. Herein we present a proposal with a methodology based on microprojects in DIY desktop machines (MicroP-DIY-DkM). The main idea is to consolidate students' theoretical background using motivating microprojects in which foreign entities act as petitioners. The students will also receive a broad view of current state of manufacturing technologies. At the same time, English language and Information and Communication Technologies skills can be promoted by our methodology. We provide information about the implementation of several examples of these microprojects, which were applied in the technical subject 'Manufacturing Technology'. The use of open source DIY-DkM offers students the possibility to understand essential principles of industrial technologies and processes. According to our surveys, students' scores and success rate results, the methodology proposed demonstrated its convenience to be applied in technical subjects. Students showed greater motivation level and success rate than previous years using conventional methods. Limitation of the proposal and possible means of improvement are also included.
\end{abstract}

Keywords: Active learning, PBL, Microproject, DIY machines, open source. 


\section{Introduction}

The society of the $21^{\text {st }}$ century shows radical differences from previous centuries, and students are not apart from this change. Today students live in a complex world that is saturated with a huge amount of information with multiple interpretations (Barnett, 2007). The $21^{\text {st }}$ century university has to stimulate a will to learn in students to face this "super complex" world (Barnett, 2007). This can be done through the adaptation of the learning environments for inspiring students to understand deeply and to use this understanding appropriately (Barnett, 2007; McCune and Entwistle, 2011). Additionally, labour markets are demanding professionals with problem-solving capabilities, leadership skills, and adaptation capabilities for international changing environments. This situation is boosting universities worldwide to update their traditional teaching methods and provide professional that meet companies' requirements. The European Space of Higher Education (EHEA), aware of the situation, has reformulated the European educational patterns to put the spotlight on the students. In this sense, active learning is an excellent candidate that has been successfully applied in technical university degrees (Prince, 2004; Rodriguez et al., 2015; Yelamarthi and Drake, 2015). Essentially, it promotes in the student the disposition to understand for oneself through simulations of real life situations (Andersson et al., 2000). Some examples of particular methods to implement active learning are project-based learning (PBL), cooperative learning and simulation of real life problems. PBL promotes students' active work throughout the planning, development and final evaluation of different projects with real-world applications (Gary, 2015). In (Fernández-Ceniceros et al., 2015; Fernandez-Ceniceros et al., 2014), we proposed a PBL methodology based on microprojects focused on emerging manufacturing technologies and international collaboration between universities. In this paper, we bring a new proposal in which the manufacturing systems are greatly enhanced with 'do it yourself' (DIY) desktop machines. DIY is a building method in which individuals employ raw and semi-raw materials and components to produce objects or machines, without the direct aid of experts (Wolf and McQuitty, 2011). The expansion of this building method is being benefited greatly with the emerging open-source movement (RepRap, GNU, Arduino, Linux, etc.). The use of DIY desktop machines (DIY-DkM) brings important advantages and enormous benefits for the implementation of the PBL learning strategies. These are some of the advantages provided:

- Lower cost of DIY machines compared to commercial ones.

- Safer systems than industrial machines.

- DIY-DkM have more appropriate size than most of commercial machines.

- Easy access to the technology. The DIY-DkMs chosen for this proposal are open source designs. This means that all the information regarding the mechanical design, electronics and software are available to anyone. This is one of the most 
important aspect of the DIY-DkM, as the students can understand the technological principles of the process from inside (Pearce, 2013).

Herein, we describe the methodology based on microprojects in DIY desktop machines (MicroP-DIY-DkM) together with the detailed formulation of several examples to apply in the 'Manufacturing Technology' subject. Results are summarised all together with experiences performed during several academic years.

\section{Summary of the MicroP-DIY-DkM methodology}

The steps involved in the methodology are presented in Figure 1. The Innovation Group (I. G.) along with the international entity coordinate these activities.

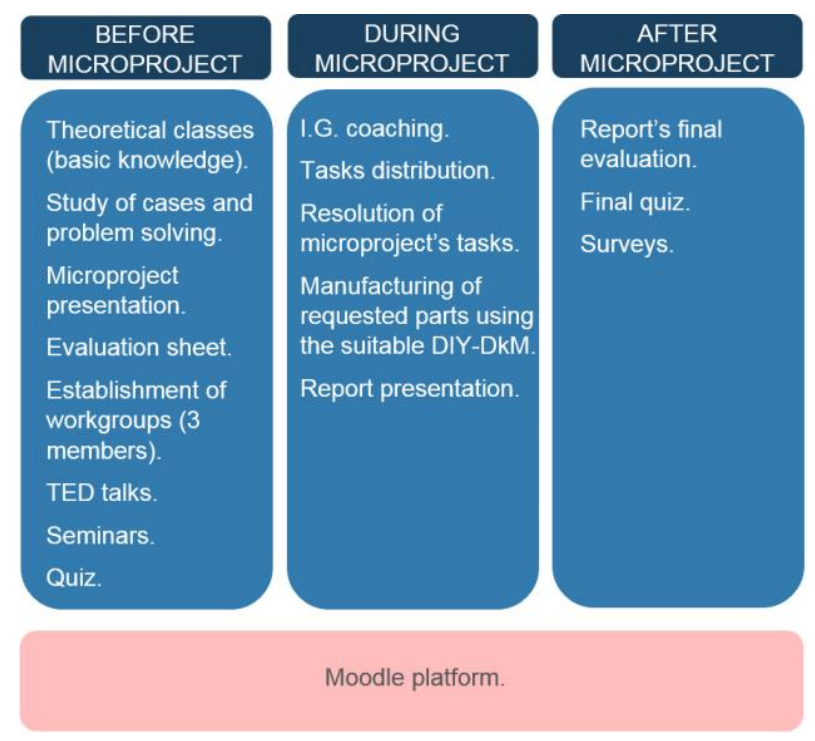

Figure 1. Scheme of the MicroP-DIY-DkM methodology.

\section{Microproject based on DIY-DkM}

MicroP-DIY-DkM provides a great opportunity to implement the knowledge acquired during classes and understand the technological principles of important industrial processes. Previous experiences validate the use of DIY approach for educational purposes (Pearce, 2013). Georgia Institute of Technology implemented a 'maker space' named 'Invention Studio' that offers the opportunity to students to learn through DIY-projects (Invention Studio, 2016). Other group pointed out that the capacity of prototyping ideas combining digital fabrication with engineering design integrates important aspects like mathematics, science, and engineering concepts into a highly motivating context (Chiu et al., 2013). 


\subsection{MicroP-DIY-DkM for the subject 'Manufacturing Technology'}

The microprojects (Table 1) starts with a request formulated from a foreign petitioner (Centre of Drug Research, Finland) to the students. The petitioner asks to each team for the manufacture of a simple device or a component with strict specifications. Students will create the model of the device/piece using CAD tools and then it will be manufactured by the proper DIY-DkM (Figure 2). Before that, students need to analyse each technology behind the DIY-DkM to understand their principles and the relations between process and machine components and imaging other applications for the machines.
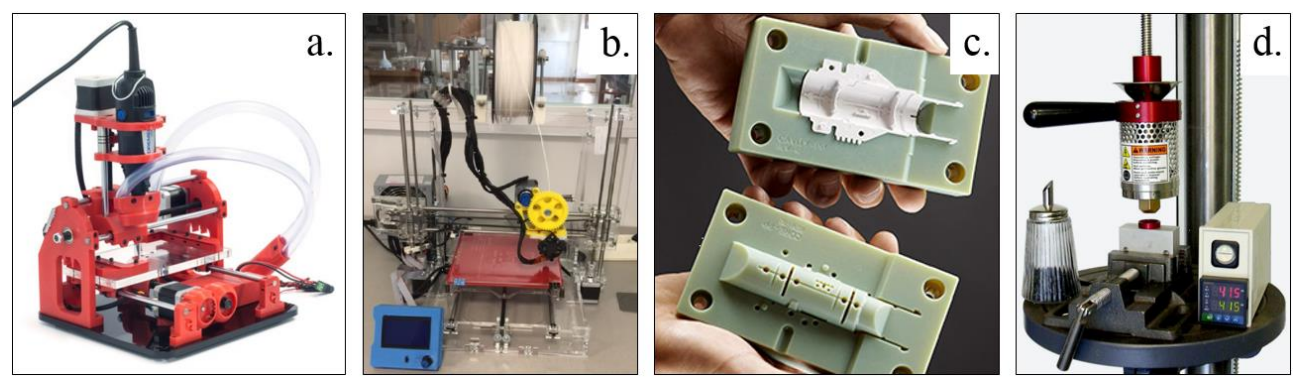

Figure 2. Microprojects' DIY-DkM: a. bq Cyclone (bq, 2016), b. Graber i3, c. Injected pieces and its printed mould (Stratasys, 2015), d. PIM-Model-20A of LNS Technologies, to convert a driller press into a plastic injection machine (LNS-Technologies, 2015).

Table 1. Four MicroP-DIY-DkM for the subject 'Manufacturing Technology'.

\begin{tabular}{|l|l|l|l|l|}
\cline { 2 - 5 } \multicolumn{1}{|c|}{} & $\begin{array}{l}\text { MP1: Milling } \\
\text { designed devices } \\
\text { using DIY CNC } \\
\text { milling machine }\end{array}$ & $\begin{array}{l}\text { MP2: Printing } \\
\text { designed pieces } \\
\text { on a DIY } \\
\text { RepRap 3D } \\
\text { printer. }\end{array}$ & $\begin{array}{l}\text { MP3: Rapid } \\
\text { manufacturing } \\
\text { of an injection } \\
\text { mould (IM) } \\
\text { using a 3D } \\
\text { printer. }\end{array}$ & $\begin{array}{l}\text { MP4: } \\
\text { Manufacture } \\
\text { of plastic } \\
\text { pieces on a } \\
\text { DIY-Dk IM } \\
\text { machine. }\end{array}$ \\
\hline Introduction & $\begin{array}{l}\text { Milling is a } \\
\text { common industrial } \\
\text { process for } \\
\text { machining } \\
\text { different material } \\
\text { to parts with } \\
\text { controlled (CNC) } \\
\text { shapes. }\end{array}$ & $\begin{array}{l}\text { Additive } \\
\text { manufacturing } \\
\text { (AM), refers to } \\
\text { the production of } \\
\text { a 3D object by } \\
\text { creating } \\
\text { successive cross- } \\
\text { sectional layers. }\end{array}$ & $\begin{array}{l}\text { Industrial } \\
\text { manufacturing } \\
\text { process for } \\
\text { producing plastic } \\
\text { parts by injecting } \\
\text { melted material } \\
\text { into a mould. 3D } \\
\text { printing mould } \\
\text { prototypes. }\end{array}$ & $\begin{array}{l}\text { The plastic } \\
\text { mould printed } \\
\text { during MP 3 } \\
\text { will be used to } \\
\text { manufacture the } \\
\text { prototype of the } \\
\text { requested piece. }\end{array}$ \\
\hline $\begin{array}{l}\text { The petitioner ask } \\
\text { for proper dies and } \\
\text { punches that will } \\
\text { be used in a further } \\
\text { process to produce } \\
\text { pills. }\end{array}$ & $\begin{array}{l}\text { The petitioner } \\
\text { asks for a proper } \\
\text { plastic } \\
\text { pharmaceutic } \\
\text { device to use as a } \\
\text { unit-dose drug } \\
\text { supplier. }\end{array}$ & $\begin{array}{l}\text { The petitioner } \\
\text { urgently request } \\
\text { the design and } \\
\text { manufacture of a } \\
\text { mould to test a } \\
\text { prototype of a } \\
\text { dosing-spoon. }\end{array}$ & $\begin{array}{l}\text { The petitioner } \\
\text { request the } \\
\text { dosing-spoon } \\
\text { prototype using } \\
\text { in the mould } \\
\text { printed in the } \\
\text { MP 3. }\end{array}$ \\
\hline Machine & bq Cyclone. & Three RepRap 3D & The same RepRap & IM machine \\
\hline
\end{tabular}


Pernía-Espinoza, A.; Sanz-García, A.; Sodupe-Ortega, E.; Antoñanzas-Torres, J.; Antoñanzas-Torres, F.; Urraca-Valle, R.

\begin{tabular}{|c|c|c|c|c|}
\hline & $\begin{array}{l}\text { Affordable price: } \\
500 €(\mathrm{a} \\
\text { commercial one is } \\
\text { above } 25 \mathrm{~K} €) \text {. }\end{array}$ & $\begin{array}{l}\text { printers: Graber } \\
\text { i3, BCN3D+ and } \\
\text { MendelMax 1.5. }\end{array}$ & $\begin{array}{l}\text { 3D printers used } \\
\text { in MP } 2 .\end{array}$ & $\begin{array}{l}\text { based on the } \\
\text { workshop drill } \\
\text { press. Low cost: } \\
600 € \text {. }\end{array}$ \\
\hline $\begin{array}{l}\text { Basic } \\
\text { principles } \\
\text { (Safety } \\
\text { considerat.: } \\
\text { SC) }\end{array}$ & $\begin{array}{l}\text {-Tool types, } \\
\text { movements. } \\
\text { - SC. } \\
\text {-Influence of } \\
\text { cutting parameters } \\
\text { on the piece } \\
\text { quality, tool wear, } \\
\text { etc. } \\
\text {-G-code. } \\
\text {-Steps to go from } \\
\text { CAD model to G- } \\
\text { code and to } \\
\text { machining. }\end{array}$ & $\begin{array}{l}\text { - RepRap } \\
\text { philosophy, AM, } \\
\text { materials. } \\
\text { - SC. } \\
\text { - Influence of } \\
\text { process } \\
\text { parameters on the } \\
\text { piece quality. } \\
\text { - G-code. } \\
\text { - Steps from CAD } \\
\text { models to G- } \\
\text { codes and to } \\
\text { printing. }\end{array}$ & $\begin{array}{l}\text { - CAD of moulds. } \\
\text { - CFD simulation } \\
\text { of the IM using } \\
\text { Autodesk } \\
\text { Moldflow } \\
\text { (Moldflow, 2016). } \\
\text { - Moulds manuf. } \\
\text { - Suited plastic } \\
\text { material. } \\
\text { - Especial } \\
\text { considerations. }\end{array}$ & $\begin{array}{l}\text { - Differences } \\
\text { regarding a } \\
\text { commercial } \\
\text { machine. } \\
\text { - SC. } \\
\text { - Polymers } \\
\text { suited to be } \\
\text { injected. } \\
\text { - Setting the } \\
\text { process } \\
\text { parameters. }\end{array}$ \\
\hline $\begin{array}{l}\text { Other } \\
\text { applications }\end{array}$ & $\begin{array}{l}\text { Circuit board } \\
\text { tracks, cutting, } \\
\text { engraving, drilling. }\end{array}$ & $\begin{array}{l}\text { Tissue regen., } \\
\text { fashion and } \\
\text { design, house } \\
\text { building, etc. }\end{array}$ & $\begin{array}{l}\text { Manufac. of } \\
\text { punch and dies for } \\
\text { forming } \\
\text { processes. }\end{array}$ & $\begin{array}{l}\text { Custom-made } \\
\text { pieces, pieces } \\
\text { with metallic } \\
\text { inserts, etc. } \\
\end{array}$ \\
\hline $\begin{array}{l}\text { Student's } \\
\text { workload } \\
\text { (homework: } \\
\text { HW) }\end{array}$ & $\begin{array}{l}\text { 1/5 ECTS. } 5 \mathrm{~h}(2 \mathrm{~h} \\
\mathrm{HW}+3 \mathrm{~h} \text { lab). }\end{array}$ & $\begin{array}{l}\text { 1/5 ECTS. } 5 \text { h }(2 \mathrm{~h} \\
\mathrm{HW}+3 \mathrm{~h} \text { lab). }\end{array}$ & $\begin{array}{l}\text { 1/4 ECTS. } 6 \text { h: } \\
(3 \mathrm{~h} \mathrm{HW}+3 \mathrm{~h} \text { lab) }\end{array}$ & $\begin{array}{l}\text { 1/5 ECTS. } 3 \mathrm{~h} \\
(1 \mathrm{~h} \mathrm{HW}+2 \mathrm{~h} \\
\text { lab). }\end{array}$ \\
\hline
\end{tabular}

Regarding the student's workload, it is important to point out that the laboratory hours are scheduled to ensure that only few groups ( 2 or 3 ) are working at the laboratory at the same time. In this way, groups are tutored in intensive sessions to get the maximum performance. Other microprojects that could be incorporated are: 'Cutting materials using a DIY-Dk Laser' and 'Welding of metal parts using a modified DIY-Dk 3D printer'.

\section{Results and discussion}

Since the academic year 2013-2014, the students filled an anonymous survey at the end of each course to evaluate their interest in the teaching/learning methodology presented herein and then evaluate it in comparison with the traditional methods. The questions are summarised in Figure 3. The answers were in a 1 to 4 scale, where 1 represented 'low' and 4 'very high', except for dichotomous Q1 ('Yes'/'No' question). Due to the limitations of space, answers 3 and 4 were grouped together. Therefore, Figure 4 and Figure 3 show the percentage of students answering 'high 'or 'very high' to the questions Q2 to Q4. 


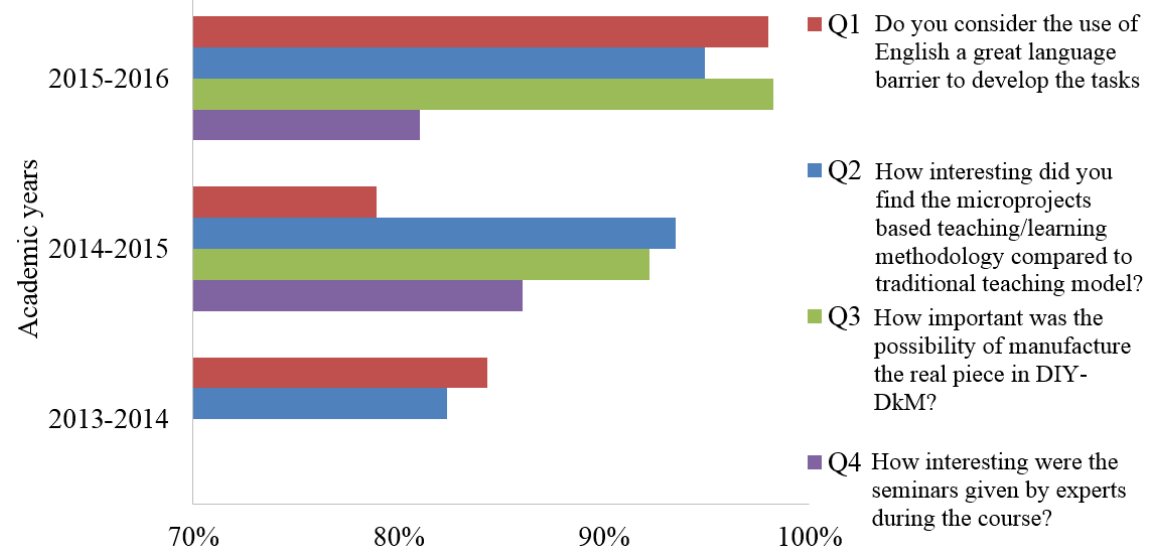

Figure 3. Percentage of students answering 'Yes' to Q1 (red bars) and percentage of students answering 'high' or 'very high' to Q2 (blue bars), Q3 (green bars) and Q4 (purpura bars) in the final survey for academic years 20132014 to 2015-2016.

As shown in Figure 3, by the lack of two of the four bars for the course 2013-2014, DIYDkM to manufacture the requested pieces (related to Q3) and the seminars given by experts (related to Q4) were improvements implemented during the academic year 2014-2015. Figure 3 also indicate that the use of English did not seem to be an important barrier to the proper development of the objectives stated in the microprojects. Moreover, the students considering of high or very high interest the use of microprojects as educational resource rises every academic year. The interest has increased since the incorporation of DIY-DkM to the methodology in course 2014-2015 (from 82\% in course 2013-2014 to 95\% in course 2015-2016). Figure 4 represents the average score and success rates of two periods: before and after implementing microproject teaching/learning methodology. The results for the traditional teaching were from 2007 to 2010, in contrast to the microproject methodology that was implemented from 2013 to 2016. According to these results, the convenience of implementing the microproject teaching/learning model proposed for this technical subject is clearly demonstrated. 
Pernía-Espinoza, A.; Sanz-García, A.; Sodupe-Ortega, E.; Antoñanzas-Torres, J.; Antoñanzas-Torres, F.; Urraca-Valle, $R$.

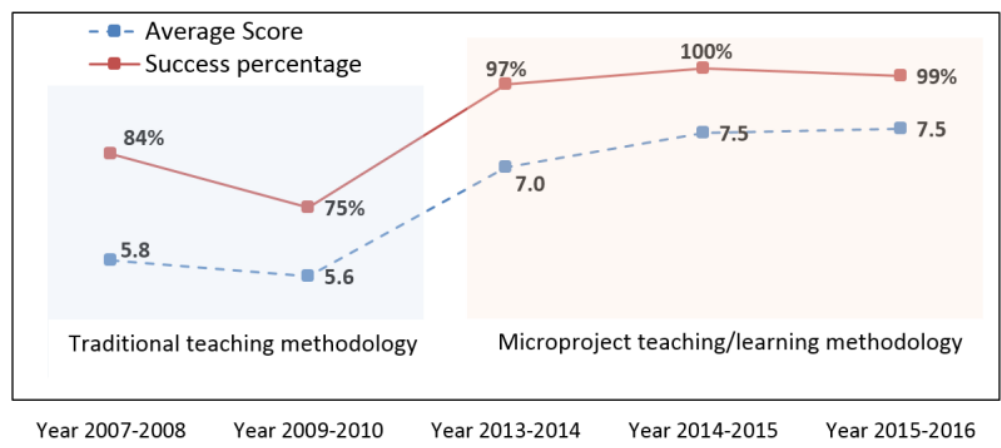

Figure 4. "Manufacturing Technology" subject average score and success rate for years from 2007 to 2016.

The research presents some shortcomings. As every academic year all students participated in the experience, there is no control group (CG) against which the methodology can be compared (Rodriguez et al., 2015). It would be interesting to let the students decide, at the beginning of the course, between participating in the MicroP-DIY-DkM methodology or to attend the classes and been evaluated by using a final exam. In this way, we could count on a CG. Another means of improvement would be to conduct pre and post-surveys (at the beginning at the end of the course) to assess the influence of the MicroP-DIY-DkM methodology on technical knowledge, transverse and generic competences (Carmenado et al., 2012; Rodriguez et al., 2015). Questions about their perception on generic competences like solving problems, teamwork, time management, leadership, etc. before and after the course could provide evidences of the positive effect of methodology proposed. All of these surveys could be also related to the final scores achieved by the students; in this particular case, a non-anonymous survey would be required.

\section{Conclusions}

We presented a methodology based on micro-projects using DIY desktop machines together with the formulation of several examples applied for the subject 'Manufacturing Technology'. Through this methodology students implemented the knowledge acquired in classroom facing real-world problems. At the same time, they became familiar with the use of English and ICTs during the communication with the foreign petitioner. The use of open source DIY-DkM provided the students with the possibility of understanding the principles of the industrial processes from inside, relating the theoretical knowledge with the machine's components. According to the surveys, students showed higher satisfaction with this educational method than using the traditional teaching system. Students' average score and success rate drastically rose and maintained in a high level when applying the microproject-based methodology proposed. There is, however, still room for improvement that will be implemented in future courses. 


\section{Acknowledgements}

The authors would like to acknowledge University of La Rioja for the financial support received through the program 'Proyectos de Innovación Docente 2015/2016', as well as for the fellowships FPI-UR to train researchers (E. S., J. A., R. U. and F. A.). The authors also want to express their gratitude to the Instituto de Estudios Riojanos (IER) and to the Banco Santander for the project PROFAI 13/06. One of the authors, A.S.G., would also like to acknowledge the financial support with the grant No. 273689 (FINSKIN) and the mobility grants No. 276371 (VATURP) and No. 286793 (VASCBIOEXP) by the Academy of Finland. We would like to thank to the special collaboration of all student involved in this experience.

\section{References}

Andersson, P., Carpenter, D., Christie, M., Duque, M., Farreras, M., Graaff, E., 2000. Active Learning in Engineering Education.

Barnett, R., 2007. A Will to Learn. Open University Press, Buckingham, UK bq, 2016. Kit Cyclone.

Carmenado, I.d.l.R., Rodríguez, B.F., Gajardo, F.G., 2012. Methodological Proposal for Teamwork Evaluation in the Field of Project Management Training. Procedia - Social and Behavioral Sciences 46, 1664-1672.

Chiu, J., Bull, G., Berry, R., III, Kjellstrom, W., 2013. Teaching Engineering Design with Digital Fabrication: Imagining, Creating, and Refining Ideas, In: Mouza, C., Lavigne, N. (Eds.), Emerging Technologies for the Classroom. Springer New York, pp. 47-62.

Fernández-Ceniceros, J., Sanz-García, A., Antoñanzas-Torres, F., Alía-Martínez*, M., Pernía-Espinoza, A., 2015. Microproject-based teaching/learning methodology focused on emerging technologies and international entities cooperation. 1st International Conference on Higher Education Advances, HEAd'15.

Fernandez-Ceniceros, J., Sanz-Garcia, A., R., U.-V., Martinez-de-Pison-Ascacibar, F., Pernia-Espinoza, A., 2014. Modelo de Enseñanza-Aprendizaje basado en microproyectos para la asignatura Tecnología de Fabricación, CUIEET 2014. XXII Congreso Universitario de Innovación Educativa en las Enseñanzas Técnicas, Almaden, Spain.

Invention Studio, 2016. Georgia Institute of Technology.

LNS-Technologies, 2015. Plastic injection PIM-shooter model 20A.

McCune, V., Entwistle, N., 2011. Cultivating the disposition to understand in 21st century university education. Learning and Individual Differences 21, 303-310.

Moldflow, A., 2016. Moldflow.

Pearce, J.M., 2013. Commentary Open-source hardware for research and education. Physics Today 66, 8-9.

Prince, M., 2004. Does Active Learning Work? A Review of the Research. Journal of Engineering Education 93 (3), 223-231. 
Pernía-Espinoza, A.; Sanz-García, A.; Sodupe-Ortega, E.; Antoñanzas-Torres, J.; Antoñanzas-Torres, F.; Urraca-Valle, $R$.

Rodriguez, J., Laveron-Simavilla, A., del Cura, J.M., Ezquerro, J.M., Lapuerta, V., Cordero-Gracia, M., 2015. Project Based Learning experiences in the space engineering education at Technical University of Madrid. Advances in Space Research 56, 1319-1330.

Stratasys, 2015. Custom Plastic Injection Molding.

Wolf, M., McQuitty, S., 2011. Understanding the do-it-yourself consumer: DIY motivations and outcomes. Academy of Marketing Science 1, 154-170.

Yelamarthi, K., Drake, E., 2015. A Flipped First-Year Digital Circuits Course for Engineering and Technology Students. Ieee Transactions on Education 58, 179-186. 